Jp.jok (Jurnal Pendidikan Jasmani, Olahraga dan Kesehatan)

http://ejurnal.budiutomomalang.ac.id/index.php/ipjok

Doi : https://doi.org/10.33503/jp.jok.v5i1.1694

\title{
The Effect of Shuttle Run and Zig-Zag Run Training On Dribbling Skills
}

\author{
Rachmat Hidayat $^{\text {1), A. Heri Riswanto }}{ }^{2)}$, M. Iqbal Has anuddin ${ }^{3)}$ \\ Program Studi Pendidikan Jasmani \\ Fakultas Keguruan dan Ilmu Pendidikan \\ ${ }^{1,2,3}$ Universitas Muhammadiyah Palopo, Indonesia \\ Email: ${ }^{1}$ rachmathiday at1405@gmail.com, ${ }^{2}$ andihery riswanto@gmail.com. \\ 3muhammadiqbhal@gmail.com
}

\begin{abstract}
The shuttle run exercise is a form of exercise that can improve agility. The zigzag run exercise is a form of agility training that involves the use of bollards and stakes. UM Palopo futsal players must have good dribbling skills. The conditions experienced by UM Palopo futsal players still often make mistakes in their dribbling skills. The lack of skills possessed by UM Palopo futsal players is due to the lack of agility training models that can support the achievements of futsal players. This study aims to reveal the effect of shuttle run and zig-zag run training on dribbling skill. The method used is a quasi-experimental (quasi-experimental). The population is 20 people from UKM Futsal UM Palopo. The sampling technique is purposive sampling. The data collection technique used the dribbling skill instrument and was analyzed by using the sig level $t$ test. $=0.05$. The results of the analysis show that there is a significant effect of shuttle run with a value of $t_{\text {count }}$ value of $20,904>t_{\text {table }}$ of 1,812 and $p_{\text {value }}$ that is $0.000<0.05$. Zig-zag run with $t_{\text {count }}$ value of $26,826>t_{\text {table }}$ of 1,812 and $p_{\text {value }}$ that is $0.000<0.05$. The improvement in shuttle run training with an average value of 17.55 and zig-zag run training with an average value of 15.61 and a significant value of $0.000<0.05$. It can be concluded that the zig-zag run is more effective in improving dribbling skills.
\end{abstract}

Keywords: Shuttle Run, Zig-Zag Run, Dribbling, Futsal

\section{Pengaruh Latihan Shuttle Run dan Zig-Zag Run terhadap Keterampilan Menggiring Bola}

\begin{abstract}
ABSTRAK
Latihan shuttle run adalah bentuk latihan yang dapat meningkatkan aqility. Latihan zig-zag run merupakan bentuk latihan kelincahan yang melibatkan penggunaan tonggak dan patok. Pemain futsal UM Palopo harus memiliki keterampilan menggiring bola yang baik. Kondisi yang dialami pemain futsal UM Palopo masih sering melakukan kesalahan-kesalahan dalam melakukan keterampilan menggiring bola. Kurangnya keterampilan yang dimiliki oleh pemain futsal UM Palopo disebabkan karena kurangnya model latihan aqility yang dapat menunjang prestasi pemain futsal. Penelitian ini bertujuan untuk mengungkap pengaruh latihan shuttle run dan zig-zag run terhadap keterampilan menggiring bola. Metode yang digunakan adalah eksperimen semu (quasi eksperimental). Populasi adalah sebanyak 20 orang UKM Futsal UM Palopo. Teknik pengambilan sampel adalah purposive sampling. Teknik pengumpulan data menggunakan instrumen keterampilan menggiring bola dianalis is menggunakan uji t taraf sig. $\alpha$ $=0.05$. Hasil analis is menunjukkan ada pengaruh yang signifikan latihan shuttle run deng an nilai $\mathrm{t}_{\text {hitung }}=20.904>\mathrm{t}_{\text {tabel }}=1.812$ dan $\mathrm{p}_{\text {value }}=0,000<0,05$. Latihan zig-zag run dengan nilai $\mathrm{t}_{\text {hitung }}=$ $26.826>t_{\text {tabel }}=1.812$ dan $\mathrm{p}_{\text {value }} 0,000<0,05$. Perbedaan pengaruh latihan shuttle run dengan nilai rata-rata sebesar 17.55 dan latihan zig-zag run sebesar 15.61 dan $\mathrm{p}_{\text {value }} 0.000<0,05$. Latihan zig-zag run lebih efektif dalammeningkatkan keterampilan menggiring bola.
\end{abstract}

Kata Kunci: ShuttleRun,Zig-Zag Run, Meng giring Bola, Futsal

Info Artikel

Dikirim

Diterima

10 Oktober 2021

: 15 November 2021

Dipublikasikan : 30 November 2021
(C) 2021 IKIP BUDI UTOMO MALANG

P-ISSN 2613-9421

E-ISSN 2654-8003

\footnotetext{
Alamat korespondensi: rachmathidavat1405@gmail.com

Universitas Muhammadiyah Palopo, Jl. Jend Sudirman No.Km. 03, Binturu, Wara Sel., Kota Palopo, Sulawesi Selatan 91922, Indonesia
} 
114 Rachmat Hidayat $^{1}$, A. Heri Riswanto ${ }^{2)}$, M. Iqbal Hasanuddin ${ }^{3)}$.Jp.jok (Jurnal Pendidikan. Jasmani, Olahraga dan Kesehatan). 5(1) 113-125

\section{PENDAHULUAN}

Unit Kegiatan Mahasiswa (UKM) adalah wadah kegiatan kemahasiswaan yang membantu anggota mengembangkan minat, bakat, dan keterampilan tertentu. UKM Futsal UM Palopo merupakan Unit Kegiatan Mahasiswa di Universitas Muhammadiyah Palopo yang menggunakan tempat latihan di lapangan outdoor Program Studi Pendidikan Jasmani. UKM Futsal UM Palopo adalah salah satu tim futsal yang berafiliasi dengan Universitas Muhammadiyah Palopo yang atlitnya didukung oleh mahasiswa dari berbagai fakultas. Ini menekankan penguasaan teknik dasar futsal selain menjadi te mpat bermain futsal dengan baik. UKM Futsal UM Palopo berupaya untuk mendukung bakat dan minat seluruh pecinta futsal.

Futsal ada lah olahraga sangat kompleks yang membutuhkan teknik serta strategi permainan yang sangat baik. Demikian pula dalam hal kemampuan aspek fisik. Futsal berbeda secara signifikan dari olahraga lain dalam beberapa hal (Gunawan, 2018). Futsal adalah olahraga sifatnya dinamis, karena pemain dituntut bergerak secara aktif, membutuhkan skill teknik yang mendukung dan memiliki kemauan yang kuat (Syafaruddin, 2019). Futsal dimainkan oleh 5 anggota dari setiap tim dan diperbolehkan memiliki pemain pengganti. Futsal dimainkan dengan bola yang relatif kecil serta berat dari bola sepak (Purnomo \& Irawan, 2021). Tujuan olahraga futsal yaitu memanipulasi bola dan kaki untuk memasukkan bola ke gawang lawan (Nosa et al., 2019).

Menggiring bola (dribbling) didefinisikan sebagai suatu teknik menggiring bola (Fatchurahman et al., 2019). Menggiring bola adalah teknik yang mendasar, pemain futsal harus mampu melewati lawan dan kedua teknik itu sangat berpengaruh terhadap aqility (Indra Fahlefi et al., 2021). Dalam futsal dan sepak bola, menggiring bola memiliki tujuan dengan maksud berlari, berjalan, berputar dan berbelok sesuai dengan kemampuan ada supaya bola dalam mudah diambil oleh lawan (Hasan et al., 2020). Menggiring bola hanya dilakukan ketika menguntungkan diri sendiri, yaitu bebas dari lawan (Novsir et al., 2020).

Latihan adalah suatu prosedur yang dilakukan secara sistematis dan berulang dalam jangka waktu yang lama, dengan beban latihan yang meningkat, untuk meningkatkan rangsangan gerak tubuh secara keseluruhan (Muhammad Ihsan Shabih et al., 2021). Latihan adalah proses sistematis melakukan hal yang 
sama berulang-ulang sambil meningkatkan jumlah beban latihan dan intensitas latihan yang meningkat dari waktu ke waktu (Prayuda \& Firmansyah, 2017). Semakin sering anda berlatih dengan unit latihan yang tepat, semakin baik pemainnya (Setiawan et al., 2021). Latihan bertujuan untuk membantu atlet dalam hal keterampilan serta prestasi olahraga mereka semaksimal mungkin (Hutomo Surya Adi , Kristiyanto Agus, 2019).

Shuttle Run adalah bentuk latihan dalam meningkatkan aqility (Ardianda \& Arwandi, 2018). Ini dapat dicapai dengan lari secara bolak balik dengan cepat yakni 8 kali sesuai jarak 5 meter. Ketika di suatu titik yang menjadi target, dengan cepat merubah arah ke titik lain (Malasari, 2019). Latihan shuttle run dirancang untuk meningkatkan kelincahan dengan lari bolak-balik secara cepat mulai di satu titik kemudian berlari pada titik lain dalam jarak yang telah ditentukan (Indra Fahlefi et al., 2021). Hasil dari latihan shuttle run adapun tujuan yakni dapat meningkatkan kelincahan terhadap menggiring bola (Fatchurahman et al., 2019)

Lari Zig-zag adalah latihan kelincahan yang melibatkan penggunaan tonggak dan patok. Sedangkan pada pelaksanaannya atlit lari dengan cepat secara berbelok-belok pada satu bidang ke bidang lain dengan melalui beberapa patok sambil mengingat dasar-dasar latihan zig-zag run yaitu lari dengan cepat pada dua batas yaitu kurang lebih 2,4 meter dan memberikan tantangan, training tersebut dilakukan secara cepat (Malasari, 2019). Lari zig-zag adalah komponen gerak kelincahan meliputi bentuk gerakan kelincahan seperti berlari dengan mengubah arah dan posisi tubuh, kecepatan, dan keseimbangan (Muhammad Ihsan Shabih et al., 2021).

Deskripsi hasil penelitian yang telah dilakukan tentang pengaruh latihan shuttle run dan zig-zag run dapat meningkatkan kelincahan pada atlet sepakbola usia 12-14 tahun SSB Kepuharjo Soccer School (Wicahyo 2021). Secara umum telah banyak penelitian tentang peningkatan kelincahan, namun peneliti dalam penelitian ini berusaha untuk membahas pendekatan teknik dasar dalam permainan futsal. Inovasi penelitian adalah menambahkan variabel keterampilan menggiring bola. Target pencapaian tersebut diharapkan pada penelitian ini bahwa keterampilan menggiring bola yang kurang maksimal harus dimulai sejak dini dan 
116 Rachmat Hidayat ${ }^{1}$ ， A. Heri Riswanto ${ }^{2)}$, M. Iqbal Hasanuddin ${ }^{3}$.Jp.jok (Jurnal Pendidikan. Jasmani, Olahraga dan Kesehatan). 5(1) 113-125

pemberian model latihan agar dapat mendukung mahasiswa dalam bermain futsal serta mencapai sebuah prestasi yang maksimal.

Berdasarkan hasil observasi langsung dilapangan pada saat pertandingan futsal pada kejuaraan futsal antar mahas iswa Se-Luwu Raya dan Tana Toraja yang dilaksanakan di Sinar Setuju sebelum masa pandemi menunjukkan bahwa keterampilan yang dimiliki oleh mahasiswa UKM Futsal UM Palopo dalam bermain futsal belum maksimal, yang berakibat pada permainan yang kurang optimal. Pemain futsal UM Palopo masih sering melakukan kesalahan - kesalahan dalam melakukan keterampilan menggiring bola, akibatnya bola yang di giring mengenai pemain lain dan terlihat kaku serta tidak terarah kemana bola akan diarahkan. Kurangnya keterampilan yang dimiliki oleh pemain futsal UM Palopo disebabkan karena kurangnya model latihan aqility yang dapat menunjang prestasi pemain futsal.

Secara rinci permasalahan penelitian adalah : (1) Apakah ada pengaruh latihan shuttle run dan zig-zag run terhadap keterampilan menggiring bola. (2) Apakah ada perbedaan pengaruh latihan shuttle run dan zig-zag run terhadap keterampilan menggiring bola. Hasil penelitian terdahulu oleh (Ardianda \& Arwandi, 2018) mengatakan bahwa terdapat pengaruh dan perbedaan pengaruh yang positif antara hasil latihan zig-zag run dan latihan shuttle run yang dilakukan sesuai kemampuan dribbling. Permasalahan tersebut menjadi kajian konferhensif pada pene litian ini, dengan harapan dapat me mberikan sumbangsi pemikiran dan solusi terhadap permasalahan yang diangkat.

Solusi yang diajukan untuk mengatasi permasalahan tersebut maka diperlukan suatu jenis atau model latihan yang mampu menjawab permasalahan tersebut yaitu dengan memberikan latihan aqility seperti latihan shuttle run dan zig-zag run untuk meningkatkan dan mengembangkan fisik secara keseluruhan. Urgensi penelitian sebagai sumber informasi baru berupa referensi ilmiah yang berasal dari temuan penelitian, yang menjadi sumber utama dalam menyusun dan melaksanakan jalannya proses pembinaan dilapangan, dapat berupa kajian ilmiah (bahan ajar) Mata Kuliah Futsal pada Prodi Pendidikan Jasmani. 


\section{METODE}

Metode penelitian ini adalah eksperimen dengan tujuan dapat mengungkapkan pengaruh latihan latihan shuttle run dan latihan zig-zag run terhadap keterampilan menggiring bola. Rancangan desain penelitian sebagai berikut :



Gambar 1. Rancangan Desain Penelitian

Sebelum perlakuan (treatment) dilaksanakan, terlebih dahulu diberikan pretest keterampilan menggiring bola untuk mendapatkan data awal. Kemudian diberikan perlakuan ( treatment) untuk kelompok latihan shuttle run dan zig-zag run dengan ketentuan WFH (work from home) selama 16 kali pertemuan sesuai rincian 3 kali dalam satu minggu dengan durasi waktu 60 menit. Dan dipantau dengan menggunakan aplikasi E-learning UM Palopo. Tes akhir (posttest) untuk mengungkap pengaruh setelah diberikan perlakuan. Pretest dan posttest dilakukan secara tatap muka di lapangan outdoor UM Palopo dengan memperhatikan protokol kesehatan sesuai ketentuan yang ada.

Populasi adalah seluruh atlit futsal yang terdaftar pada UKM Olahraga futsal UM Palopo sebanyak 20 orang. Sampel adalah UKM Futsal UM Palopo sebagai objek yang diteliti. Teknik pengambilan sampel adalah purposive sampling yaitu pertimbangan tertentu oleh peneliti, sehingga sampel dalam penelitian ini adalah UKM Futsal UM Palopo sebanyak 20 orang. Sampel dibagi menjadi dua kelompok secara ordinary matched pairing supaya sampel tersebut sifatnya homogen.

Teknik pengumpulan data dalan penelitian yakni tes keterampilan menggiring bola dengan nilai validitas 0,99 dan reliabilitas 0,70 (Ikhsan, 2017). Dengan tujuan dapat mengetahui keterampilan menggiring bola disertai perubahan yang cepat. Data hasil penelitian dianalisis dengan uji persyaratan yakni uji normalitas dan uji homogenitas sesuai taraf signifikansi $\alpha=0,05$. Selanjutnya dianalisis menggunakan uji t-test. 
118 Rachmat Hidayat ${ }^{1}$ ， A. Heri Riswanto ${ }^{2)}$, M. Iqbal Hasanuddin ${ }^{3}$.Jp.jok (Jurnal Pendidikan. Jasmani, Olahraga dan Kesehatan). 5(1) 113-125

\section{HASIL DAN PEMB AHASAN}

\section{HASIL}

Analisis deskriptif data sesuai dengan gambaran umum data penelitian pretest dan posttest keterampilan menggiring bola. Analis is deskriptif meliputi mean, range, minimun dan maksimun.

Tabel 1. Hasil analisis deskriptif pretest dan posttest keterampilan menggiring bola

\begin{tabular}{cccccc}
\hline Variabel & N & Mean & Range & Min & Max \\
\hline Pretest Shuttle Run & 10 & 21.62 & 4.78 & 19.34 & 24.12 \\
Posttest Shuttle Run & 10 & 17.55 & 3.17 & 16.01 & 19.18 \\
Pretest Zig-zag Run & 10 & 20.89 & 4.27 & 18.77 & 23.04 \\
Posttest Zig-zag Run & 10 & 15.61 & 3.24 & 14.10 & 17.34 \\
\hline
\end{tabular}

Hasil analsiis deskriptif diketahui nilai pretest shuttle run dengan sampel (N) 10 diketahui nilai rata-rata sebesar 21.62, rentang sebesar 4.78, nilai minimun sebesar 19.34 dan nilai maksimun sebesar 24.12. Nilai posttest shuttle run dengan sampel (N) 10 diketahui nilai rata-rata sebesar 17.55, rentang sebesar 3.17, nilai minimun sebesar 16.01 dan nilai maksimun sebesar 19.18. Sedangkan nilai pretest zig-zag run dengan sampel (N) 10 diketahui nilai rata-rata sebesar 20.89, rentang sebesar 4.27, nilai minimun sebesar 18.77 dan nilai maksimun sebesar 23.04. Nilai posttest zig-zag run dengan sampel (N) 10 diketahui nilai rata-rata sebesar 15.61, rentang sebesar 3.24, nilai minimun sebesar 14.10 dan nilai maksimun sebesar 17.34.

Tabel 2. Hasil uji normalitas data pretest dan posttest keterampilan menggiring bola

\begin{tabular}{clllll}
\hline No & \multicolumn{1}{c}{ Variabe I } & $\begin{array}{c}\text { Shariro- } \\
\text { Wilk }\end{array}$ & Sig. & $\boldsymbol{\alpha}$ & Ket \\
\hline 1 & Pretest Shuttle Run & 0.958 & 0.763 & 0,05 & Normal \\
2 & Posttest Shuttle Run & 0.961 & 0.794 & 0,05 & Normal \\
3 & Pretest Zig-zag Run & 0.958 & 0.761 & 0,05 & Normal \\
4 & Posttest Zig-zag Run & 0.937 & 0.522 & 0,05 & Normal \\
\hline
\end{tabular}

Berdasarkan hasil uji normalitas diketahui nilai signifikan pretest shuttle run sebesar $0.763>0,05$ dan posttest shuttle run $0.794>0,05$. Sedangkan nilai signifikan pretest zig-zag run sebesar $0.761>0,05$ dan posttest zig-zag run $0.522>0,05$. Hasil kesimpulan bahwa data tersebut berdistribusi normal. 
Tabel 3. Hasil uji homogenitas keterampilan menggiring bola

\begin{tabular}{ccccc}
\hline Lavene Statistic & df1 & df2 & Sig. & Ket \\
\hline 1.322 & 1 & 18 & 0.265 & Homogen \\
\hline
\end{tabular}

Berdasarkan hasil uji homogenitas data keterampilan menggiring bola nila i levane test sebesar 1.322 dengan nilai signifikan sebesar 0.265. Hasil kesimpulan bahwa data tersebut homogen.

\section{Uji Hipotesis}

Uji t pada penelitian tersebut menggunakan paered sampel t-test dan independen sampel t-test untuk mengungkap pengaruh dan perbedaan pengaruh latihan shuttle run dan zig-zag run terhadap keterampilan menggiring bola UKM Futsal UM Palopo.

Tabel 4. Uji t berpasangan

\begin{tabular}{cccll}
\hline Variabel & N & $\begin{array}{c}\text { T- } \\
\text { Hitung }\end{array}$ & T-Tabel & Sig.(2-tailed) \\
\hline Pretest- Posttest Shuttle Run & 10 & 20.904 & 1.812 & 0,000 \\
Pretest-Posttest Zig-zag run & 10 & 26.826 & 1.812 & 0,000 \\
\hline
\end{tabular}

Dilihat dari tabel di atas dapat disimpulkan pretest-posttest shuttle run nilai $\mathrm{t}=$ hitung sebesar $20.904>\mathrm{t}=$ tabel 1.812 dan sig. (2-tailed) yaitu $0,000<$ 0,05 . Pretest-posttest zig-zag run nilai $\mathrm{t}=$ hitung sebesar $26.826>\mathrm{t}=$ tabe 11.812 dan sig. (2-tailed) yaitu $0,000<0,05$. Berarti ada pengaruh yang signifikan latihan shuttle run dan zig-zag run terhadap keterampilan menggiring bola UKM Futsal UM Palopo. Latihan shuttle run adalah cara terbaik untuk menilai kebugaran anaerobik. Akibatnya, latihan shuttle run adalah bentuk lari secara bolak-balik yang dirancang dengan mengukur kemampuan pemain untuk merubah arah dan posisi. Alhasil, unsur aqility yaitu shuttle run sangat bermanfaat dalam hal keterampilan menggiring bola. Secara alami gerakan yang dihasilkan cepat berubah arah sesuai keinginan.

Salah satu penunjang penguasaan teknik dalam permainan sepakbola salah satunya keterampilan menggiring bola adalah latihan shuttle run. Tersedianya pelatihan shuttle run bermanfaat bagi kelincahan dan kecepatan pemain saat 
120 Rachmat Hidayat ${ }^{1}$ ， A. Heri Riswanto ${ }^{2)}$, M. Iqbal Hasanuddin ${ }^{3}$.Jp.jok (Jurnal Pendidikan. Jasmani, Olahraga dan Kesehatan). 5(1) 113-125

menggiring bola (Ardiand \& Arwandi, 2018). Semakin intes latihan aqility berupa latihan shuttle run 10 meter maka akan baik pencapaian keterampilan menggiring bola pada permainan sepakbola serta untuk meningkatkan keterampilan dan kecepatan menggiring bola pada permainan sepakbola (Haris, 2021). Ada peningkatan aqility dengan metode latihan shuttle run setelah atlet sepakbola usia 12-14 tahun SSB Kepuharjo Soccer School mengikuti program latihan aqility yakni metode latihan shuttle run (Wicahyo, 2021).

Metode latihan lari zig-zag memberikan efek yang positif terhadap aqility dalam menggiring bola pada UKM Futsal UM Palopo, latihan lari zig-zag run merupakan jenis latihan yang melibatkan gerak memutar melalui tanda-tanda yang telah dibuat dengan tujuan mengajarkan kemampuan umtuk mengubah arah dengan cepat. Hasil penelitian menunjukkan bahwa latihan zig-zag dapat meningkatkan kelincahan menggiring bola (Muhammad Ihsan Shabih et al., 2021). Metode latihan lari zig-zag akan memberikan efek terhadap kemampuan menggiring bola (Ruslan \& Sangadji, 2021).

Peningkatan latihan lari zig-zag untuk meningkatkan keterampilan menggiring bola memiliki dampak yang cukup besar terhadap kemampuan menggiring bola siswa ekstrakurikuler sepakbola dilakukan dengan benar dan membutuhkan tenaga yang maksimal (Razbie et al., 2018). Hasil penelitian ini didukung oleh penelitian yang menunjukkan latihan lari zig-zag meningkatkan kelincahan dribbling bola dalam permainan futsal (Hasan et al., 2020).

Tabel 5. Uji t tidak berpasangan

\begin{tabular}{cccc}
\hline Variabel & N & Mean & Sig.(2-tailed) \\
\hline Posttest Shuttle Run & 10 & 17.55 & 0,000 \\
Posttest Zig-zag run & 10 & 15.61 & \\
\hline
\end{tabular}

Dilihat dari tabel di atas dapat disimpulkan peningkatan latihan shuttle run dengan nilai rata-rata sebesar 17.55 dan latihan zig-zag run dengan nilai rata-rata sebesar 15.61 dan nilai signifikan $0.000<0,05$. Hasil kesimpulan latihan zig-zag run sangat efektif dalam meningkatkan keterampilan menggiring bola UKM Futsal UM Palopo. Kelincahan adalah kemampuan untuk dengan cepat mengubah posisi atau gerakan tubuh saat berlari tanpa kehilangan keseimbangan, seperti pada latihan Lari zig-zag, yang menyebabkan kontraksi pada kelompok otot yang 
Rachmat Hidayat ${ }^{1)}$, A. Heri Riswanto ${ }^{2)}$, M. Iqbal Hasanuddin ${ }^{3)}$.Jp.jok (Jurnal Pendidikan. Jasmani, Olahraga dan

berbeda bergantian. Sementara shuttle run adalah bagian dari kelincahan fisik, itu juga merupakan komponen dari kelincahan mental. Shuttle Run adalah tes yang menilai aqility seseorang ditinjau dari posisi tubuh dan arah gerakan.

\section{PEMBAHASAN}

Latihan shuttle run adalah jenis latihan kelincahan di mana atlit berlari secara bolak-balik secepat mungkin dengan mengubah arah. Menggiring bola memerlukan tindakan yang cepat dan tidak terduga, oleh karena itu menguasai latihan lari shuttle cepat merupakan salah satu pemacu untuk memahami teknik menggiring bola dalam permainan futsal. Latihan shuttle run mengharuskan untuk berlari cepat dari satu titik ke titik yang lain sambil mengubah arah dengan cepat. Latihan Shuttle run dirancang dalam meningkatkan aspek aqility mengharuskan pemain untuk berlari secara bola-balik dengan cepat pada satu titik ke titik lain sesuai jarak yang ditentukan (Indra Fahlefi et al., 2021). Karena jarak yang ditempuh tidak terlalu jauh dan hanya sedikit rintangan yang harus dihadapi siswa, latihan ini lebih sering diulang da lam latihan (Wardani and Irawadi 2020). Karena adanya perubahan kontraksi otot fleksor dan ekstensor maka latihan shuttle run dapat meningkatkan kelincahan dribbling dalam permainan futsal (Primadi et al., 2021).

Latihan lari zig-zag bersifat ritmis karena subjek akan melakukan gerakan memutar untuk menghasilkan pola gerakan yang dapat digunakan untuk gerakan menggiring bola sepanjang permainan (Primadi et al., 2021). Tujuan zig-zag run adalah untuk melatih perubahan gerakan tubuh ke arah yang berliku (Tofikin \& Sinurat, 2020). Namun dalam melakukan latihan, peningkatan keterampilan menggiring bola tidak lepas dari peran pemain itu sendiri, karena pemain harus disiplin dalam menjalankan program latihan agar dapat mencapai tujuan latihan yang optimal.

The zig-zag run is a type of training that involves zig-zagging between positions in order to increase agility. The zig-zag run exercise is essential in football games because it improves agility in soccer players, particularly when dribbling (Durahim \& Hasbiah, 2019). Karena latihan zig-zag run dan shuttle run dribbling sama-sama efektif dalan melatih kelincahan, maka kedua jenis latihan ini dapat direkomendasikan sebagai alternatif dalam mengembangkan program 
latihan yang pelaksanaannya diselingi sebagai variasi latihan untuk meningkatkan konsentrasi dan menambha beban pada kaki (Fatchurahman et al., 2019).

Bentuk latihan zig-zag run sangat berpengaruh positif terhadap shuttle run (Wicahyo, 2021). Program latihan untuk dapat meningkatkan komponen kelincahan yaitu; Latihan untuk meningkatkan kelincahan adalah latihan zig-zag run dan shuttle run (Mansur et al., 2020). Latihan lari zig-zag mengharuskan peserta untuk berlari dan berputar melewati dengan cepat kerucut tanpa kehilangan keseimbangan; lari zig-zag dapat dilakukan sesuai kecepatan maksimal supaya kemampuan dribbling dapat terlihat dengan jelas; dan latihan shuttle run mengharuskan peserta untuk berlari cepat ke suatu daerah. dari titik ke titik dan harus cepat mengubah arah gerak Namun, melakukan latihan untuk meningkatkan keterampilan menggiring bola tidak lepas dari peran pemain itu sendiri, supaya atlit harus disiplin dalam menjalankan program latihan karena dapat mencapai tujuan latihan baik secara optimal. Kedua jenis latihan ini dapat meningkatkan kelincahan dribbling namun menurut para peneliti, latihan lari zig-zag memiliki dampak yang lebih besar pada keterampilan menggiring bola dari pada latihan shuttle run sesuai data dilapangan (Ardiand \& Arwandi, 2018).

Keunggulan penelitian ini yakni terletak pada pemberian model latihan aqility yakni shuttle run \& zig-zag run yang telah didesain sebagai atlernatif atau bahan masukan untuk pe latih. Keunggulan yang lain pada penggunaan E-learning UM Palopo karena mengingat masa pandemic tentunya isi menjadi opsi atau alternatif, sehingga dapat dipantau dalam menjalankan sebuah penelitian. Limitasi atau kelemahan penelitian ini terpusat pada proses penelitian. Tentunya peneliti menyadari ada beberapa kendala atau hambatan terkait penelitian tersebut dilihat dari waktu dan tempat penelitian mengingat physical distancing. Jadwal latihan untuk treatment aqility yakni kelompok latihan shuttle run dan zig-zag run dengan ketentuan WFH (work from home). Kendalanya ada atlit yang tidak memiliki lahan untuk melakukan latihan sehingga harus mencari tempat lain, terkait jadwal latihan disore hari ada diantara mahasiswa yang bersamaan dengan jadwal perkuliahan sehingga tidak sesuai jadwal yang ditetapkan. Tentunya peneliti melibatkan orang tua atlit dalam mengawasi latihan tersebut dan mengambil dokumentasi \& video sebagai bukti. 
Rekomendasi temuan penelitian tersebut yang berkaitan dengan model latihan aqility berupa zig-zag run dan shuttle run bagi pelatih pada dasarnya dapat menerapkan model latihan aqility dalam hal aspek keterampilan menggiring bola. Karena terbukti dapat meningkatkan motivasi atlit pada saat berlatih. Dalam menerapkan model latihan aqility pelatih dituntut untuk melakukan persiapan yang matang sehingga program latihan yang diberikan sangat jelas dan dapat dimengerti oleh atlit. Disarankan bagi pelatih untuk memilih model latihan yang lebih efektif dalam menunjang aspek keterampilan menggiring bola. Rekomendasi terkhusus kepada peneliti selanjutnya supaya dapat mengembangkan hasil riset tersebut dengan perluasan aspek fisik \& psikologis.

\section{SIMPULAN}

Temuan penelitian terkait model latihan aqility yakni latihan shuttle run dan zig-zag run memberikan efek positif dalam meningkatkan keterampilan menggiring bola atlit UKM Futsal UM Palopo. Tetapi dilihat dari perbedaan pengaruh, maka latihan zig-zag run lebih efektif dalam meningkatkan keterampilan meng giring bola UKM Futsal UM Palopo. Adapun has il riset dimuat dalam saran penelitian sebagai berikut : (1) Model latihan aqility dapat dijadikan sebagai alternatif dalam meningkatkan teknik dasar bermain futsal. (2) Model latihan aqility dapat dijadikan sebagai bahan ajar pada mata kuliah futsal. (3) Sebagai bahan acuan atau referensi untuk pe latih dalam menge mbangkan olahraga futsal di UM Palopo.

\section{DAFTAR RUJUKAN}

Ardianda, E., \& Arwandi, J. (2018). Latihan Zig-Zag Run dan Latihan Shuttle Run Berpengaruh Terhadap Kemampuan Dribbling Sepakbola. Jurnal Performa Olahraga, 3, 32-41.

Durahim, Darwis, \& Hasbiah. 2019. The Effect of Zig-Zag Run Exercise on Increasing Agility in the Soccer Players. International Journal of Sciences: Basic and Applied Research (IJSBAR) 48(4): 152-57.

Fahlefi, P. M. I., Multazam, A., Rahmanto, S., \& Rahim, A. F.. (2021). Perbandingan Shuttle Run Exercise Dan Ladder Drill Exercise Terhadap Kelincahan Pada Pemain Futsal. Physiotherapy Health Science (PhysioHS), 
124 Rachmat Hidayat ${ }^{1}$ ， A. Heri Riswanto ${ }^{2)}$, M. Iqbal Hasanuddin ${ }^{3}$.Jp.jok (Jurnal Pendidikan. Jasmani, Olahraga dan Kesehatan). 5(1) 113-125

2(2), 62-68. https://doi.org/10.22219/physiohs.v2i2.15195.

Fatchurahman, R., Sundari, L. P. R., Griadhi, I. P. A., Tirtayasa, K., Dinata, I. M. K., \& Dwi Primayanti, I. D. A. I. (2019). Pelatihan Zig-Zag Run Dribbling Dan Pelatihan Shuttle Run Dribbling Sama Baik Dalam Meningkatkan Kecepatan Menggiring Bola Futsal Sma Dwijendra Denpasar. Sport and Fitness Journal, 45-52. https://doi.org/10.24843/spj.2019.v07.i03.p07.

Gunawan, G. 2018. Hubungan Power Tungkai Dan Kelincahan Dengan Keterampilan Menggiring Bola Pada Permainan Futsal. Jurnal Speed 1(1): 31. https://journal. unsika.ac.id/index.php/speed/article/view/1496.

Haris, Fahrizal Mahardika. 2021. "Effect Of Shuttle Run Training On Dribbling Skills In Football Games In Grade Viii Boys Upt Smp Negeri 8 Gresik Year 2019-2020." 7(1): 22-36.

Hasan, M, N., \& Syam, N. (2020). Pengaruh Latihan Zig-Zag Run Dan Latihan Boomerang Run Terhadap Kelincahan Menggiring Bola Dalam Permainan Futsal Siswa Smp Negeri 10 Makassar. Journal of Sport and Physical Education, 1(1), 38-49. https://ojs.unm.ac.id/jspe/article/view/14822.

Hutomo, A. S., Kristiyanto, A., \& Purnama, S. K. (2019). Peningkaasastan Keterampilan Teknik Dasar Futsal Melalui Penggunaan Media Video pada Mahasiswa Putra Penghobi Futsal. Prosiding Seminar Nasional IPTEK Olahraga (SENALOG), 2(1), 21-24.

Ikhsan. (2017). Analisis Kondisi Fisik Predominan Dan Konsentrasi Terhadap Keterampilan Teknik Dasar Sepakbola Siswa SMA Negeri 1 Pitumpanua Kabupaten Wajo. Tesis tidak diterbitkan. Makassar. Program Pascasarjana Universitas Negeri Makassar.

Malasari, C. A. (2019). Pengaruh Latihan Shuttle-Run dan Zig-Zag Run terhadap Kelincahan Atlet Taekwondo. Gelanggang Olahraga: Jurnal Pendidikan Jasmani Dan Olahraga (JPJO), 3(1), 81-88. https://doi.org/10.31539/jpjo.v3i1.828.

Mansur et al. 2020. "Ana lis is Kondisi Fisik ( Kelincahan ) Atlet Cabang Olahraga Unggulan Kabupaten Kebumen Provinsi Jawa Tengah Analysis and Evaluation of Physical Condition ( Agility ) of Athlete of Special Sport in Kebumen District Central Java Province." Jurnal Olahrga Prestasi 16(2): $72-77$.

Muhammad Ihsan Shabih, Iyakrus, \& Destriani. (2021). Latihan Zig-Zag Terhadap Kelincahan Menggiring Bola Pada Atlet Sepak Bola. Jurnal Kejaora (Kesehatan Jasmani Dan Olah Raga), 6(1), 145-152. https://doi. or g/10.36526/keja ora.v6i1.1289.

Nosa, V. T. A., Sulaiman, I., Nurdin, F., \& Praniata, A. R. (2019). Model 
Pembelajaran Shooting Futsal Untuk Siswa Sma. Jurnal Pendidikan Olahraga, 8(1), 27. https://doi.org/10.31571/jpo.v8i1.1218.

Novsir, B., Defliyanto, D., \& Yarmani, Y. (2020). Pengaruh Latihan Lari Zig Zag Menggunakan Beban Terhadap Peningkatan Keterampilan Dribbling dalam Permainan Sepak Bola Pada Siswa Ekstrakurikuler SMA Negeri 4 Seluma. SPORT GYMNASTICS : Jurnal Ilmiah Pendidikan Jasmani, 1(1), 915. https://doi.org/10.33369/gymnastics.v1i1.12116.

Prayuda, A. Y., \& Firmansyah, G. (2017). Pengaruh Latihan Lari 12 Menit Dan Lari Bolak Balik Terhadap Peningkatan Daya Tahan Vo2 Max. Jp.Jok (Jurnal Pendidikan Jasmani, Olahraga Dan Kesehatan), 1(1), 13-22. https://doi.org/10.33503/jpjok.v1i1.247.

Primadi, Muhamad Baidhowi et al. 2021. Pemberian Latihan Tambahan Zig-Zag Run Lebih Baik Daripada Pemberian Latihan Tambahan Shuttle Run Dalam Meningkatkan Kelincahan Pada Program Latihan Di Akademi Opel Futsal Lamongan. Sport and Fitness Journal, 9(1):34.

Purnomo, A., \& Irawan, F. A. (2021). Analisis kecepatan dan kelincahan dalam menggiring bola pada tim futsal. Sepakbola 1 (1), 2021, 1-7,1(1), 1-7.

Razbie, R Y, A A Nurudin, and M Soleh. 2018. "Pengaruh Latihan Lari Zig-Zag Terhadap Penguasaan Teknik Dasar Dribbling Pada Permainan Sepakbola Ekstrakurikuler SDN Sungapan Kecamatan” utile: Jurnal Kependidikan. https://jurnal.ummi.ac.id/index.php/JUT/artic le/dow nload/250/106.

Setiawan, W. A., Festiawan, R., Heza, F. N., \& Kus uma, I. J. (2021). Peningkatan Keterampilan Dasar Futsal Melalui Metode Latihan Passing Aktif dan Pasif. Jurnal Pendidikan Kesehatan Rek reasi, 7(2), 270-278.

Syafaruddin, S. (2019). Tinjauan Olahraga Futsal. Altius : Jurnal Ilmu Olahraga Dan Kesehatan, 7(2). https://doi.org/10.36706/altius.v7i2.8108.

Tofikin, \& Sinurat, R. (2020). Zig-Zag Run: Metode Latihan Kelincahan Tendangan Sabit Pencak Silat. Journal Sport Area, 5(2), 177-185. https://doi. or g/10.25299/sportarea.2020.vol5(2).5333.

Wardani, A. S. P., \& Irawadi, H. 2020. Perbedaan Pengaruh Latihan Kelincahan Shuttle Run Dengan Latihan Lateral Run Terhadap Kemampuan Menggiring Bola Siswa U-14 Ssb Putra Wijaya Fc Padang. Jurnal Patriot 2(1): 62-72.

Wicahyo, A. M. 2021. Pengaruh Latihan Shuttle Run Dan Zig-Zag Run Terhadap Peningkatan Kelincahan ( Studi Eksperimen Pada Atlet Sepakbola Usia 1214 Tahun Ssb Kepuharjo Soccer School ). 